\title{
THE X-RAY METHOD APPLIED TO A STUDY OF THE CON. STITUTION OF PORTLAND CEMENT
}

\author{
By L. T. Brownmiller and R. H. Bogue
}

ABSTRACT

The X-ray diffraction method has been applied to a study of the constitution of Portland cement clinker.

It has been found that $2 \mathrm{CaO} . \mathrm{SiO}_{2}$ and $\mathrm{CaO}$ combine to form $3 \mathrm{CaO} . \mathrm{SiO}_{2}$ and not a solid solution of $2 \mathrm{CaO} \cdot \mathrm{SiO}_{2}+\mathrm{CaO}$; that $8 \mathrm{CaO} \cdot \mathrm{Al}_{2} \mathrm{O}_{3} \cdot 2 \mathrm{SiO}_{2}$ does not exist in Portland cement systems; that solid solutions are not formed between the aluminates and silicates of cement systems; and that free $\mathrm{CaO}$ is not present generally in commercial cements in amounts as great as 2.5 per cent.

The limiting amounts were determined of each cement compound that could be identified by X-ray means as employed in this study. Twenty-eight commercial cement clinkers were subjected to $\mathrm{X}$-ray examination and $3 \mathrm{CaO} . \mathrm{SiO}_{2}$ and $\beta 2 \mathrm{CaO} . \mathrm{SiO}_{2}$ were identified in each. $3 \mathrm{CaO} . \mathrm{Al}_{2} \mathrm{O}_{3}, 4 \mathrm{CaO} \cdot \mathrm{Al}_{2} \mathrm{O}_{3} \cdot \mathrm{Fe}_{2} \mathrm{O}_{3}$ and $\mathrm{MgO}$ were found in the samples which contained those compounds, by calculation, in amounts great enough to permit identification.

\section{CONTENTS}

I. Introduction

II. The X-ray method

III. The composition $3 \mathrm{CaO}+\mathrm{SiO}_{2}$

IV. The composition $8 \mathrm{CaO}+\mathrm{Al}_{2} \mathrm{O}+2$

VI. Free lime

VIII. Examination of commercial cement clinkers..... 826

IX. Summary

X. Bibliography

828

\section{INTRODUCTION}

The investigations by Rankin and Wright (1) ${ }^{1}$ on the system $\mathrm{CaO}-\mathrm{Al}_{2} \mathrm{O}_{3}-\mathrm{SiO}_{2}$ have shown that there are formed in that system, at equilibrium, in the region of Portland cement clinkers, $3 \mathrm{CaO} . \mathrm{SiO}_{2}$, $2 \mathrm{CaO} . \mathrm{SiO}_{2}$, and $3 \mathrm{CaO} . \mathrm{Al}_{2} \mathrm{O}_{3}$. More recently, other systems have been solved (2), as a result of which the compounds that can be formed at equilibrium, in the region of Portland cement clinker, have been determined for the components $\mathrm{CaO}, \mathrm{Al}_{2} \mathrm{O}_{3}, \mathrm{SiO}_{2}, \mathrm{Fe}_{2} \mathrm{O}_{3}$, and $\mathrm{MgO}$. These compounds are $3 \mathrm{CaO} . \mathrm{SiO}_{2}, 2 \mathrm{CaO} . \mathrm{SiO}_{2}, 3 \mathrm{CaO} . \mathrm{Al}_{2} \mathrm{O}_{3}, 4 \mathrm{CaO}$.$\mathrm{Al}_{2} \mathrm{O}_{3}, \mathrm{Fe}_{2} \mathrm{O}_{3}$, and $\mathrm{MgO}$.

Portland cement clinker contains, in addition to the above mentioned components, from 2 to 4 per cent of other material, as alkalies, titania, sulphates, manganese oxides, phosphates, etc. These may have some influence on the proportions of the above-mentioned compounds in the clinker, but it is improbable that they materially affect the major constitution of the commercial product.

1 The figures in parenthesis here and throughout the text relate to the reference figure in the bibliography at the end of this paper. 
The findings on the five-component system referred to are deduced from studies at the condition of equilibrium. The method used in the manufacture of Portland cement leads to the belief that a condition approaching equilibrium is attained in commercial clinker. A failure completely to reach equilibrium, however, may result in the presence of some uncombined lime and a change in the relative proportions of the other compounds, but rarely in the elimination of one of those compounds with the formation of a different compound.

Investigations (3) have been reported from this laboratory which confirm this viewpoint. The methods used in the study of phase equilibria, including thermal, microscopic, and X-ray examinations indicated that the major compounds of Portland cement clinker are $3 \mathrm{CaO} . \mathrm{SiO}_{2}, \beta 2 \mathrm{CaO} . \mathrm{SiO}_{2}, 3 \mathrm{CaO} \cdot \mathrm{Al}_{2} \mathrm{O}_{3}, 4 \mathrm{CaO} \cdot \mathrm{Al}_{2} \mathrm{O}_{3} \cdot \mathrm{Fe}_{2} \mathrm{O}_{3}$, and $\mathrm{MgO}$.

Many investigators, however, especially in Europe, have adhered to theories of constitution developed prior to the application of the phase rule, or have advanced other views which are at variance with those expressed above. Prominent among these may be mentioned the view (4) that the lime, in excess of that necessary to form $2 \mathrm{CaO} . \mathrm{SiO}_{2}$ with the silica, enters essentially into solid solution with the $2 \mathrm{CaO} . \mathrm{SiO}_{2}$; the contention (5) that $3 \mathrm{CaO} . \mathrm{SiO}_{2}$ does not exist and that the principal constituent of clinker is $8 \mathrm{CaO} \cdot \mathrm{Al}_{2} \mathrm{O}_{3} \cdot 2 \mathrm{SiO}_{2}$; the opinion (6) that the $3 \mathrm{CaO} \cdot \mathrm{Al}_{2} \mathrm{O}_{3}$ enters into solid solution with the calcium silicates; and the conclusion (7) that Portland cement clinker contains relatively large amounts of uncombined lime.

The X-ray method is peculiarly well adapted to the examination of the above theories, both as they apply in pure systems and in commercial clinkers. This was one of the objectives of this research-to present X-ray evidence bearing directly on each of the above theories to the end that the nature of the compounds in the pure systems and in commercial cement clinker may become generally established.

The second purpose of this study was to examine by $\mathrm{X}$-ray and chemical means a large number of commercial clinkers to ascertain (1) precisely what compounds could be positively identified in each and (2) the nature of the agreement between such X-ray analysis and the constitution as computed from the chemical analysis. Incidental to this part of the work, it was necessary to determine the efficiency of the X-ray method to resolve the pattern of each compound in the presence of the other compounds of the cement.

\section{THE X-RAY METHOD}

The positive identification of a crystalline compound by the microscope should include the measurement of a number of the optical properties, such as the refractive indices, optic axial angle, pleochroism, etc.; but in the case of Portland cement it is not possible to obtain all of these data for each phase present. The crystals, even of the principal constituents, usually are very fine grained and often too small to permit of satisfactory measurements. Furthermore, the crystals often are surrounded with glass or contain inclusions. For these reasons the microscopic examination of these materials has not proved entirely satisfactory, and this condition has resulted in much difference of opinion in the interpretation of the available observations. 'The X-ray method, therefore, fills a distinct need, for the results obtained with it are based on criteria which are convincing. 
During recent years the powder X-ray method for identifying compounds in the pure state or in mixtures has received considerable attention and development (8). The theoretical considerations of this method have been described in various places (9). When a powdered material is subjected to $\mathrm{X}$-radiation and the resulting spectrum photographed, there is obtained an X-ray diffraction pattern consisting of a series of lines in definite positions which are ordinarily measured from a fixed zero point and recorded as "interplanar spacings" $\left(d_{h k l}\right)$. Each crystalline chemical compound has a characteristic diffraction pattern which appears always to be the same whether the compound is present in a pure state or intermixed with other compounds. Even different crystalline forms of the same composition can be distinguished by the method; thus $\gamma-$ and $\beta-2 \mathrm{CaO}$. $\mathrm{SiO}_{2}$ have entirely different diffraction patterns (10).

The X-ray method has definite but well-understood limitations. Thus, a diffraction pattern depends on the arrangement of the atoms of a substance in crystal planes. Glass shows no such arrangement, and, hence, can not be detected by the method.

In a mixture of two compounds, it often happens that some of the lines of one pattern coincide with some of the lines of the other pattern. Hence, the greater the number of compounds, the greater the probability of coincidence of lines. Nevertheless such coincidences cause differences in intensity of the resulting lines so that the identity of a pattern may not be entirely obscured.

Of greater significance are the limitations due to the amount of a material present. As the quantity of one crystalline phase decreases, the general intensity of the pattern of that compound decreases. First the least intense lines of the pattern disappear and then the stronger lines until a certain minimum amount of the compound is reached when the strongest lines can no longer be observed. Under the most favorable conditions, quantities of material less than 2 or 3 per cent of the total can rarely be identified. For the detection of such small amounts of material, the crystals should be well developed, possess a high order of symmetry and a simple structure, and give rise to lines which do not conflict with those of the patterns of the other materials present. Only infrequently are these conditions fulfilled, so that, ordinarily, greater amounts than those mentioned above are required for the recognition of a phase.

The relative intensities of the lines as well as their positions are significant in the identification of compounds. If one line of a diffraction pattern is twice as intense as another line of the same pattern, that relation obtains whether the compound is present in a pure state or in a mixture. In a mixture of two compounds, the pattern of one is superimposed on that of the other; the general intensity of each pattern is diminished because of dilution by the other, but the relative intensities of the lines of each pattern remain the same.

Analysis of a sample of an unknown material, therefore, depends upon the recognition, by position and relative intensity, of the lines of the diffraction pattern of a pure material in that of the unknown sample. Hence, before any such analysis can be undertaken, the diffraction patterns of the pure compounds which may occur in the sample must be known. Such information has been published from this laboratory for most of the pure compounds which occur in the oxide systems of Portland cement (11). Recent improvements in 
methods and purity of samples have resulted in somewhat more precise measurement of the lines of the diffraction patterns and in more complete diffraction data, but the interplanar spacings are not found to differ essentially from those reported previously.

The apparatus used in this study was the X-ray diffraction photometer of Hull equipped with a Coolidge molybdenum water-cooled target. The cassettes for holding the films were provided with zirconium oxide filters so that the effective wave length of the rays was $0.712 \mathrm{~A}$. U. The radius of the cassettes was 8 inches. Since crystals of clinker are extremely small, the powder method of Debye and Hull (9) was found most suitable and was used exclusively in these studies. By this method the samples of clinker are ground to pass a No. 200 sieve and mounted in lead-free glass tubes of about $0.5 \mathrm{~mm}$. inside diameter. Occasionally the samples were mounted on a silk thread. To do so the finely ground clinker was mixed with collodion and the thread immersed. On withdrawing the thread, sufficient material adhered to permit a satisfactory analysis. Exposure of a sample lasted 50 hours in most cases at a tube current of about 18 milliamperes and a voltage of 30,000 .

Diffraction patterns were obtained of 28 samples of clinker, both domestic and foreign. For the complete analysis of any one sample, several exposures were necessary. Normal exposure of 50 hours was sufficient for the identification of most of the lines; occasionally, however, overexposure and overdevelopment of the films were resorted to for the strengthening of the weaker lines. On the other hand, underexposure and underdevelopment sometimes provided a means for the resolution of two lines lying very close to each other, which lines ordinarily merged to form one broad band. In the identification of the patterns of various pure compounds in clinker a capillary tube was filled one half of its length with the samples of clinker and the other half with the compound to be identified. Thereby the patterns of the two were exactly opposite each other on the film and measurement of the lines became more precise, since then irregularities of two films were avoided. Altogether some 200 exposures were made in the course of this study.

The precision of measurement of the interplanar spacing increases as the interplanar spacing decreases. It may be pointed out, however, that weak lines are more difficult to estimate than stronger lines so that measurement in such cases may not be as accurate; often also they lie close to strong lines so that their true position may be misjudged. Measurements were made on the centers of the lines, but in some cases, where a line is broad, the precise allocation of the center is difficult. Many of these broad lines may be found, by special exposures, to consist of two lines. Where such lines occur in the patterns, the position of each component line is recorded in the following tables, together with the reading that ordinarily is obtained where the two lines appear as one broad band.

In order to determine the relative precision of the measurements of the interplanar spacings, 15 films of the diffraction pattern of tricaclium aluminate were examined. Six lines in each film were ineasured. A summary of the results is given in Table 1. It may be noted that the difference between the extreme values, as measured, diminish from 0.020 at interplanar spacings of 2.690 to 0.004 at interplanar spacings of 1.202. The average deviations from the mean 
through the same range diminish from 0.004 to 0.001 . This serves as a general indication of the precision of measurements in this study but some variation may occur due to the differences in sharpness or intensity of the lines as above noted.

$\mathrm{T}_{\mathrm{ABLE}}$ 1.-The precision of measurement of six lines in the $X$-ray diffraction pattern of $3 \mathrm{CaO} \cdot \mathrm{Al}_{2} \mathrm{O}_{3}$

Line No.

\begin{tabular}{|c|c|c|c|c|c|c|}
\hline & \multicolumn{6}{|c|}{ Line No. } \\
\hline & 1 & 2 & 3 & 4 & 5 & 6 \\
\hline Mean (15 films) & 2. 690 & 2. 202 & 1.905 & 1.555 & 1. 346 & 1.202 \\
\hline $\begin{array}{l}\text { Maximum value } \\
\text { Minimum value. }\end{array}$ & $\begin{array}{l}2.700 \\
2.680\end{array}$ & $\begin{array}{l}2.210 \\
2.195\end{array}$ & $\begin{array}{l}1.910 \\
1.897\end{array}$ & $\begin{array}{l}1.557 \\
1.551\end{array}$ & $\begin{array}{l}1.348 \\
1.344 \\
\end{array}$ & $\begin{array}{l}1.205 \\
1.201\end{array}$ \\
\hline Difference between extreme values...-. & .020 & .015 & .013 & .006 & .004 & .004 \\
\hline Average deviation from mean & .004 & .004 & .003 & .002 & .001 & .001 \\
\hline
\end{tabular}

The intensity of the lines was measured visually. This is the procedure commonly employed and is satisfactory for qualitative observations. A photodensitometer (12) has been developed in this laboratory, however, for the more precise estimation of the intensities of the lines which will be employed in a later study on the quantitative X-ray determination of the compounds present.

\section{THE COMPOSITION $3 \mathrm{CaO}+\mathrm{SiO}_{2}$}

The existence of $3 \mathrm{CaO} . \mathrm{SiO}_{2}$ in the $\mathrm{CaO}-\mathrm{Al}_{2} \mathrm{O}_{3}-\mathrm{SiO}_{2}$ system (1) and in Portland cement clinker (3) has been established by phaso equilibria studies combined with microscopic examinations. A number of European investigators, however, have been unable to accept the existence of that compound (5), and the suggestion has been urged (4) that the lime enters into solid solution with dicalcium silicate. The evidence obtained by the $\mathrm{X}$-ray method on this problem is important because of the rigid nature of the criteria in identification of compounds in the X-ray diffraction patterns. These data, set down below, offer impressive confirmation of the existence of the tricalcium silicate in the $\mathrm{CaO}-\mathrm{Al}_{2} \mathrm{O}_{3}-\mathrm{SiO}_{2}$ system and in Portland cement clinker.

Samples were prepared of the following compositions: No. 1, $2 \mathrm{CaO}+\mathrm{SiO}_{2} ;$ No. $2,2 \frac{1}{3} \mathrm{CaO}+\mathrm{SiO}_{2} ; \mathrm{No} .3,2 \frac{1}{2} \mathrm{CaO}+\mathrm{SiO}_{2} ;$ No. 4 , $23 / 4 \mathrm{CaO}+\mathrm{SiO}_{2}$; and $\mathrm{No} .5,3 \mathrm{CaO}+\mathrm{SiO}_{2}$.

These were made from calcium carbonate and quartz of high purity as indicated by the partial analyses (13) of these materials given in Table 2.

TABle 2.-Partial analyses of raw materials

\begin{tabular}{|c|c|c|}
\hline & $\begin{array}{c}\text { Calcium } \\
\text { car- } \\
\text { bonate }\end{array}$ & Quartz \\
\hline $\begin{array}{l}\mathrm{CaO} \\
\mathrm{MgO} \\
\mathrm{SiO}_{2} \\
\mathrm{Al}_{2} \mathrm{O}_{3} \\
\mathrm{Fe}_{2} \mathrm{O}_{3} \\
\mathrm{Cl} \\
\mathrm{SO}_{3} \\
\mathrm{CO}_{2}\end{array}$ & $\begin{array}{r}55.55 \\
.07 \\
.03 \\
.01 \\
.00 \\
.04 \\
.00 \\
43.63\end{array}$ & $\begin{array}{r}0.02 \\
.00 \\
99.37 \\
.50 \\
.03 \\
.00 \\
.00\end{array}$ \\
\hline Loss on ignition.- & 43.97 & .11 \\
\hline
\end{tabular}


The weighed portions of sample No. $1\left(2 \mathrm{CaO}+\mathrm{SiO}_{2}\right)$, ground to pass completely through the No. 200 sieve, were mixed in a pebble mill for 3 hours, then formed into bars about 10 inches long by 1 inch cross section and heated in an updraft gas furnace for $2 \frac{1}{2}$ hours at $1,500^{\circ} \mathrm{C}$. The clinker was ground and a sample taken for microscopic and $\mathrm{X}$-ray examination and for the free $\mathrm{CaO}$ test. The balance of the sample was then mixed in the pebble mill as before with an additional quantity of calcium carbonate to give the composition of No. $2\left(2 \frac{1}{3} \mathrm{CaO}+\mathrm{SiO}_{2}\right)$, and the mixture again burned for $2 \frac{1}{2}$ hours at $1,500^{\circ} \mathrm{C}$. This process was repeated with additional increments of calcium carbonate until all of the samples of the different compositions had been obtained. The free $\mathrm{CaO}$ test showed that no lime remained uncombined in any of the samples.

Each of the samples was subjected to X-radiation and the diffraction patterns obtained. No. 1 showed only the pattern of $\gamma 2 \mathrm{CaO} . \mathrm{SiO}_{2}$. No. 2 showed the lines of a new pattern, which we will call $x$, superimposed upon that of $\gamma 2 \mathrm{CaO} . \mathrm{SiO}_{2}$. In No. 3 , the lines of $\gamma 2 \mathrm{CaO} . \mathrm{SiO}_{2}$ disappeared and were replaced by the pattern of the beta form of that compound. The pattern of $x$ also was present, and in greater intensity than in No. 2. No. 4 showed the same pattern as No. 3 except that the lines of $\beta 2 \mathrm{CaO} . \mathrm{SiO}_{2}$ were weaker and the lines of $x$ were stronger. No. 5 showed only the pattern of $x$. In no case were the lines of $\mathrm{CaO}$ observed nor was there found any shift in position of the lines of the dicalcium silicate nor of $x$ following a change in composition.

The formation of a distinctive pattern when the composition $3 \mathrm{CaO}+\mathrm{SiO}_{2}$ is reached, together with the appearance and position of this pattern in other mixtures, meets the requirements for assigning to that composition an identity as the chemical compound $3 \mathrm{CaO} \cdot \mathrm{SiO}_{2}$. When larger amounts of $\mathrm{CaO}$ are present than represented by the composition $3 \mathrm{CaO}+\mathrm{SiO}_{2}$ the pattern of $\mathrm{CaO}$ is found to be superimposed upon that of the $3 \mathrm{CaO} . \mathrm{SiO}_{2}$. Between the compositions $3 \mathrm{CaO}+\mathrm{SiO}_{2}$ and $2 \mathrm{CaO}+\mathrm{SiO}_{2}$ there always are observed the lines of $3 \mathrm{CaO} . \mathrm{SiO}_{2}$ and $\beta$ or $\gamma 2 \mathrm{CaO} . \mathrm{SiO}_{2}$. The intensities of the two patterns are proportional to the calculated amounts of those compounds that should be present. When sufficient attention is given in the preparation to insure that a condition of equilibrium is reached, the lines of $\mathrm{CaO}$ are absent. The failure to observe any shift in position of the lines of those compounds when $\mathrm{CaO}$ is added indicates that no solid solution is formed or that the amount of such solution, if there is any at all, is too small to be detected.

The principal interplanar spacings of the patterns of $\mathrm{CaO}$, $3 \mathrm{CaO} . \mathrm{SiO}_{2}$, and $\beta 2 \mathrm{CaO} . \mathrm{SiO}_{2}$ are listed in Table 3 .

An inspection of the data will show that the pattern of each is distinctive. There are, indeed, several lines which are found to be coincident in two or three of the patterns, but a sufficient dissimilarity is found, both in position and intensity of lines, definitely to preclude any interpretation which would assign to tricalcium silicate the composition of a mixture or solid solution of the other two compounds.

Recently Janecke (14) has interpreted X-ray data reported from this laboratory (10) as indicating that $3 \mathrm{CaO} \cdot \mathrm{SiO}_{2}$ is a mixture of $\beta 2 \mathrm{CaO} . \mathrm{SiO}_{2}$ and $\mathrm{CaO}$. In order the better to demonstrate that the pattern of $3 \mathrm{CaO} . \mathrm{SiO}_{2}$ is quite distinct from that of $\beta 2 \mathrm{CaO} \cdot \mathrm{SiO}_{2}$ with $\mathrm{CaO}, \mathrm{X}$-ray diffraction photographs were made as follows: One 
half of a capillary glass tube for exposure was filled with pure tricalcium silicate; the other half was filled with an equimolar mixture of beta dicalcium silicate and calcium oxide. The resulting photograph shows the patterns of the two materials on opposite sides of the same film. X-ray diffraction patterns do not reproduce well for printing, but the reproduction shown in Figure 1 reveals the striking dissimilarity of the two patterns. The upper pattern is that of the mixture of $\beta 2 \mathrm{CaO} . \mathrm{SiO}_{2}$ and $\mathrm{CaO}$. The lower pattern is that of pure $3 \mathrm{CaO} \cdot \mathrm{SiO}_{2}$. It is at once apparent that $3 \mathrm{CaO} \cdot \mathrm{SiO}_{2}$ is not composed of $\beta 2 \mathrm{CaO} . \mathrm{SiO}_{2}+\mathrm{CaO}$.

A careful measurement of the interplanar spacings shows that the mixture of $\beta 2 \mathrm{CaO} . \mathrm{SiO}_{2}$ and $\mathrm{CaO}$ gives a superimposed pattern of those two compounds. It conforms to a combination of the patterns of those compounds as listed in Tabel 3. The pattern of the $3 \mathrm{CaO} \cdot \mathrm{SiO}_{2}$ is identical with that listed for $3 \mathrm{CaO} \cdot \mathrm{SiO}_{2}$ in Table 3.

$\mathrm{T}_{\mathrm{ABLE}}$ 3. - The principal interplanar spacings of $\mathrm{CaO}, 3 \mathrm{CaO} . \mathrm{SiO}_{2}$ and $\mathrm{\beta}^{2 \mathrm{CaO}} . \mathrm{SiO}_{2}{ }^{1}$

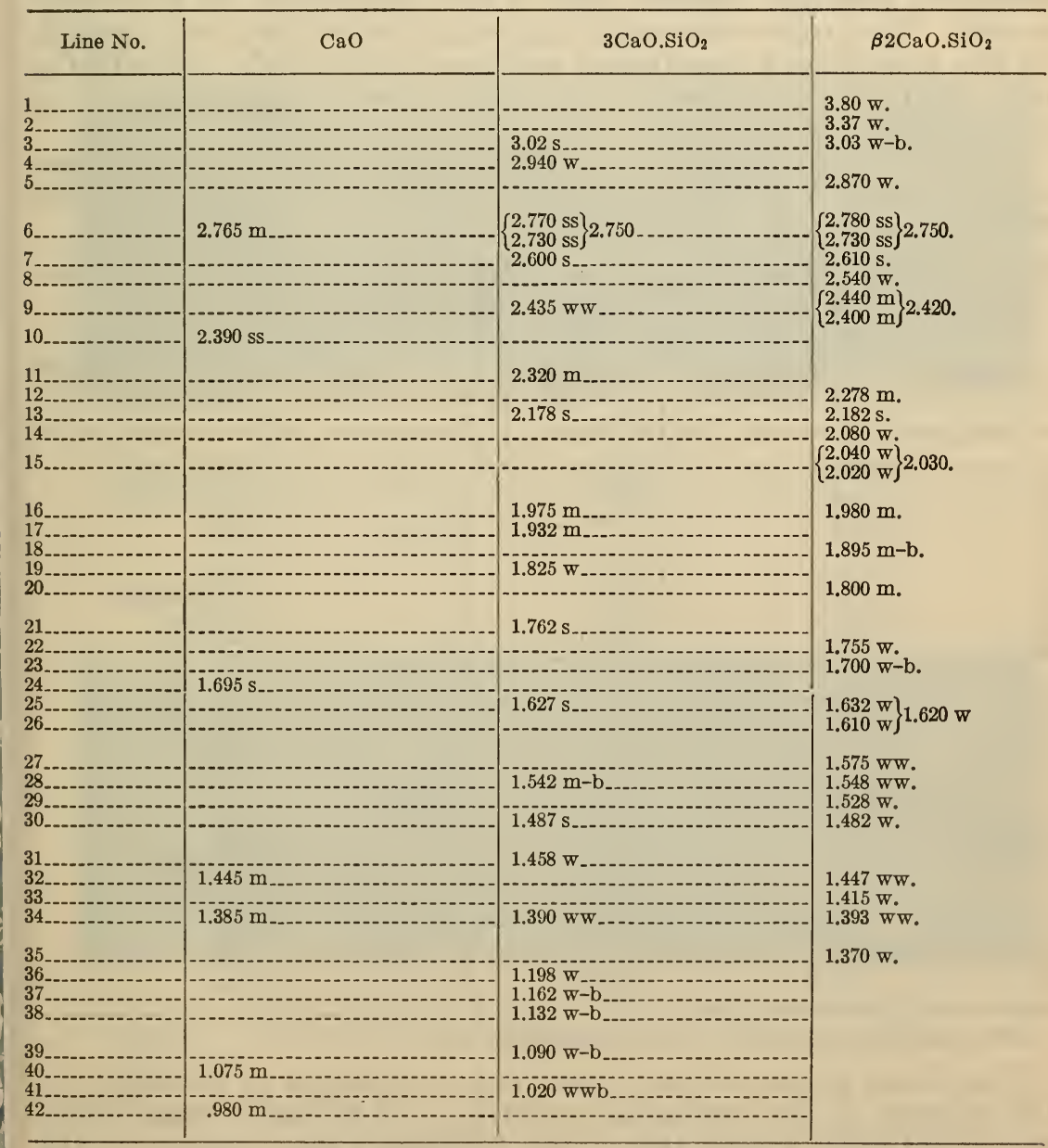

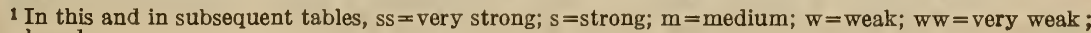
$\mathrm{b}=$ brosd. 


\section{THE COMPOSITION $8 \mathrm{CaO}+\mathrm{Al}_{2} \mathrm{O}_{3}+2 \mathrm{SiO}_{2}$}

In 1912 Jänecke (5) published his first paper setting forth his discovery that the "alite," or principal compound of Portland cement, consists of $8 \mathrm{CaO} \cdot \mathrm{Al}_{2} \mathrm{O}_{3} \cdot 2 \mathrm{SiO}_{2}$. This contribution was quickly refuted by Rankin and Wright (15), who pointed out that such a compound did not exist in the $\mathrm{CaO}-\mathrm{Al}_{2} \mathrm{O}_{3}-\mathrm{SiO}_{2}$ system and that a mixture of that composition at equilibrium consists of $3 \mathrm{CaO} . \mathrm{SiO}_{3}$, $2 \mathrm{CaO} \cdot \mathrm{SiO}_{2}$, and $3 \mathrm{CaO} \cdot \mathrm{Al}_{2} \mathrm{O}_{3}$. The conclusion of Rankin and Wright has been confirmed in this laboratory (16), but the existence of $8 \mathrm{CaO} \cdot \mathrm{Al}_{2} \mathrm{O}_{3} \cdot 2 \mathrm{SiO}_{2}$, designated "Jäneckite," (17) as the "alite" of Portland cement clinker, has been reaffirmed by Jänecke (18).

The X-ray evidence upon which the opinion of this laboratory is based is set down below:

The purported composition $8 \mathrm{CaO} \cdot \mathrm{Al}_{2} \mathrm{O}_{3} \cdot 2 \mathrm{SiO}_{2}$ was prepared (16) in the form of fused drops by the method described by Dyckerhoff (4) and found by microscopical examination to consist largely of the elongated fiber-like crystals said to be characteristic of that compound. The drops were crushed and examined by the X-ray method. At the same time a mechanical mixture of $3 \mathrm{CaO} . \mathrm{SiO}_{2}, \beta 2 \mathrm{CaO} . \mathrm{SiO}_{2}$, and $3 \mathrm{CaO} \cdot \mathrm{Al}_{2} \mathrm{O}_{3}$ in the same molecular proportion was subjected to $\mathrm{X}$-radiation.

The X-ray data on these materials are given in Table 4, together with the pattern of $\mathrm{CaO}$, which was found also to be present in the fused drops.

TABLE 4.-Interplanar spacings of the $8 \mathrm{CaO}+\mathrm{Al}_{2} \mathrm{O}_{3}+2 \mathrm{SiO}_{8}$ preparations, mixtures of $3 \mathrm{CaO} . \mathrm{SiO}_{2}, \beta 2 \mathrm{CaO} . \mathrm{SiO} \mathrm{O}_{2}$ and $3 \mathrm{CaO} . \mathrm{Al}_{2} \mathrm{O}_{3}$, and of $\mathrm{CaO}$

\begin{tabular}{|c|c|c|c|c|}
\hline Line No. & $\begin{array}{l}\text { Fused drops of } 8 \mathrm{CaO} \\
+\mathrm{SiO}_{2}+2 \mathrm{SiO}_{2}\end{array}$ & $\begin{array}{c}\text { Mixture of } \mathrm{C}_{3} \mathrm{~S} \text {, } \\
\beta \mathrm{C}_{2} \mathrm{~S} \text {, and } \mathrm{C}_{3} \mathrm{~A}\end{array}$ & $\mathrm{CaO}$ & $\begin{array}{l}\text { Compounds giving rise } \\
\text { to lines in pattern of } \\
\text { fused drops }\end{array}$ \\
\hline & 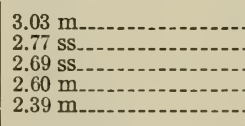 & 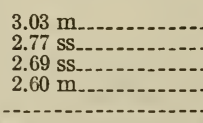 & $2.765 \mathrm{~m}$ & $\begin{array}{l}\mathrm{C}_{3} \mathrm{~S} . \\
\mathrm{C}_{3} \mathrm{~S}, \beta \mathrm{C}_{2} \mathrm{~S}, \mathrm{CaO} . \\
\mathrm{C}_{3} \mathrm{~A} . \\
\mathrm{C}_{3} \mathrm{~S} . \\
\mathrm{CaO} .\end{array}$ \\
\hline $\begin{array}{l}6 \\
7 \\
8 \\
9 \\
10\end{array}$ & $\begin{array}{l}2.27 \mathrm{ww} \\
2.18 \mathrm{~S} \\
2.03 \mathrm{ww} \\
1.975 \mathrm{w} \\
1.895 \mathrm{~s}\end{array}$ & 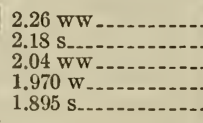 & & $\begin{array}{l}\beta \mathrm{C}_{2} \mathrm{~S} . \\
\mathrm{C}_{3} \mathrm{~S}, \beta \mathrm{C}_{2} \mathrm{~S}, \mathrm{C}_{3} \mathrm{~A} \\
\beta_{\mathrm{C}_{2}} \mathrm{~S}, \mathrm{C}_{3} \mathrm{~A} . \\
\mathrm{C}_{3} \mathrm{~S}, \mathrm{C}_{3} \mathrm{~A} . \\
\mathrm{C}_{3} \mathrm{~A} .\end{array}$ \\
\hline $\begin{array}{l}11-\ldots \ldots \\
12 \\
13 \\
14 \\
15\end{array}$ & 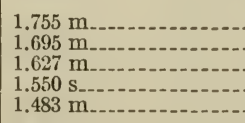 & $\begin{array}{l}1.758 \mathrm{~m} \\
1.630 \mathrm{w} \\
1.552 \mathrm{~s}_{\ldots} \\
1.485 \mathrm{w}_{\ldots}\end{array}$ & $1.695 \mathrm{~s}$ & $\begin{array}{l}\mathrm{C}_{3} \mathrm{~S} . \\
\mathrm{CaO} \\
\mathrm{C}_{3} \mathrm{~S}, \beta \mathrm{C}_{2} \mathrm{~S} \\
\mathrm{C}_{3} \mathrm{~A} . \\
\mathrm{C}_{3} \mathrm{~S} .\end{array}$ \\
\hline 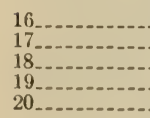 & $\begin{array}{l}1.450 \mathrm{w} \\
1.385 \mathrm{ww} \\
1.345 \mathrm{w} \\
1.200 \mathrm{~m} \\
1.095 \mathrm{w}_{2}\end{array}$ & $\begin{array}{l}1.342 \mathrm{w}_{2} \\
1.202 \mathrm{~m}_{-} \\
1.093 \mathrm{w}_{-} . . .\end{array}$ & $\begin{array}{l}1.445 \mathrm{~m}_{-} \\
1.385 \mathrm{~m} \\
1.201 \mathrm{w}_{-} \\
1.101 \mathrm{w}_{-}\end{array}$ & $\begin{array}{l}\mathrm{CaO} . \\
\mathrm{CaO}_{3} \\
\mathrm{C}_{3} \mathrm{~A} . \\
\mathrm{C}_{3} \mathrm{~A}, \mathrm{CaO} . \\
\mathrm{C}_{3} \mathrm{~S}, \mathrm{CaO} .\end{array}$ \\
\hline $\begin{array}{l}21---. \\
22--\cdot \\
23--- \\
24---.\end{array}$ & $\begin{array}{r}1.076 \mathrm{ww}_{-} \\
1.020 \mathrm{w} \ldots \\
.980 \mathrm{ww}_{-} . . \\
.900 \mathrm{ww}_{-. .}\end{array}$ & $.896 \mathrm{ww}$ & $1.075 \mathrm{~m}$ & $\begin{array}{l}\mathrm{CaO} . \\
\mathrm{C}_{3} \mathrm{~A} . \\
\mathrm{CaO} . \\
\mathrm{C}_{3} \mathrm{~A} .\end{array}$ \\
\hline
\end{tabular}

Note: $\mathrm{C}_{3} \mathrm{~S}=3 \mathrm{CaO} . \mathrm{SiO}_{2} ; \mathrm{C}_{2} \mathrm{~S}=2 \mathrm{CaO} . \mathrm{Si}_{2} \mathrm{O} ; \mathrm{C}_{3} \mathrm{~A}=3 \mathrm{CaO} . \mathrm{Al}_{2} \mathrm{O}_{3}$.

The X-ray pattern of the fused drops is observea to be similar to the pattern of the mechanical mixture of $3 \mathrm{CaO} . \mathrm{SiO}_{2}, \beta 2 \mathrm{CaO} . \mathrm{SiO}_{2}$, and $3 \mathrm{CaO} \cdot \mathrm{Al}_{2} \mathrm{O}_{3}$ except that a few additional lines appear in the former which may be noted to be due to free $\mathrm{CaO}$. 
B. S. Journal of Research, RP233

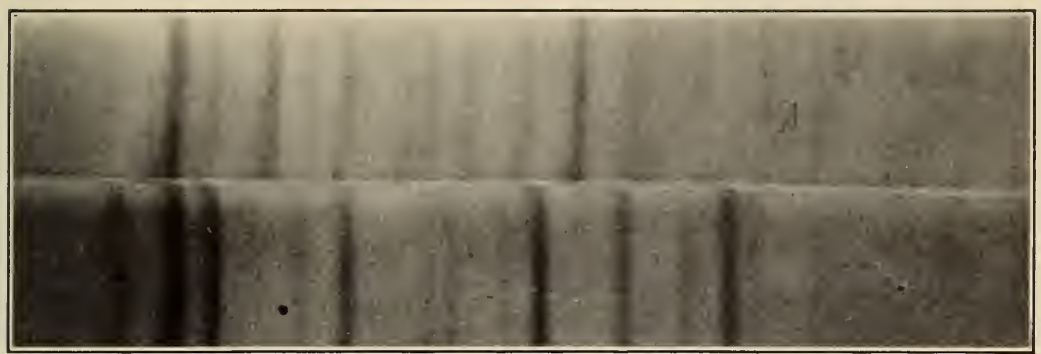

Figure 1.-Upper, pattern of equimolar mixture of $\mathrm{\beta}_{2} \mathrm{CaO} . \mathrm{SiO}_{2}$ and $\mathrm{CaO}$. Lower, pattern of pure $3 \mathrm{CaO} . \mathrm{SiO}_{2}$

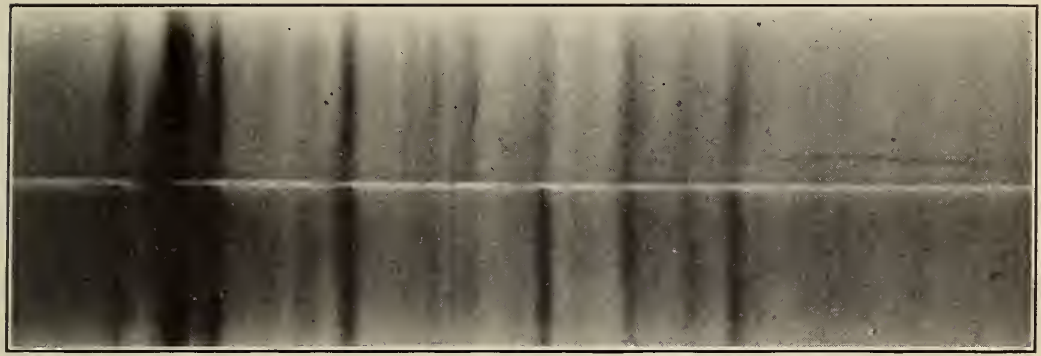

FigURe 2.-Upper, mixture of 47 per cent $3 \mathrm{CaO} . \mathrm{SiO}_{2}, 47$ per cent $\mathrm{\beta 2} \mathrm{CaO} . \mathrm{SiO}_{2}$, and 6 per cent $3 \mathrm{CaO} . \mathrm{Al}_{2} \mathrm{O}_{3}$. Lower, composition of same calculated content burned at $1.525^{\circ} \mathrm{C}$.

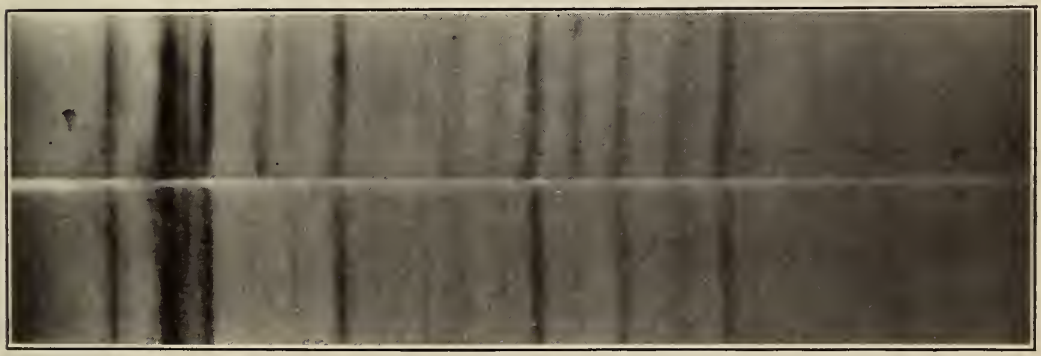

FigURE 3.-Upper, clinker burned at $1,435^{\circ} \mathrm{C}$. which contains 2.8 per cent free $\mathrm{CaO}$. Lower, clinker burned at $1,500^{\circ} \mathrm{C}$. which contains 0.1 per cent free $\mathrm{CaO}$ 
In a recent paper, Jänecke (19) presents some information obtained by the $\mathrm{X}$-ray examination of the composition " $8 \mathrm{CaO} \cdot \mathrm{Al}_{2} \mathrm{O}_{3} \cdot \mathrm{SiO}_{2}$." In the pattern of that composition Jänecke reports that he finds the lines of $\beta 2 \mathrm{CaO} \cdot \mathrm{SiO}_{2}, 3 \mathrm{CaO} \cdot \mathrm{Al}_{2} \mathrm{O}_{3}$, and $\mathrm{CaO}$, together with a few additional lines which he ascribed to "Jäneckite." Unfortunately he makes no attempt at a comparison of those lines with the pattern of tricalcium silicate.

From the evidence presented it appears that Jänecke's compound is a mixture of $3 \mathrm{CaO} . \mathrm{SiO}_{2}, \beta 2 \mathrm{CaO} \cdot \mathrm{SiO}_{2}$, and $3 \mathrm{CaO} \cdot \mathrm{Al}_{2} \mathrm{O}_{3}$ with a small amount of $\mathrm{CaO}$.

\section{SOLID SOLUTIONS OF ALUMINATES IN SILICATES}

It has been reported (6) that $3 \mathrm{CaO} \cdot \mathrm{SiO}_{2}$ and $3 \mathrm{CaO} \cdot \mathrm{Al}_{2} \mathrm{O}_{3}$ are capable of entering into solid solution with each other and that they exist as a solid solution in cement clinker. It is extremely difficult by optical methods to identify positively small amounts of $3 \mathrm{CaO} \cdot \mathrm{Al}_{2} \mathrm{O}_{3}$ in the presence of $3 \mathrm{CaO} \cdot \mathrm{SiO}_{2}$. The indices of the two compounds (1) are practically identical, 1.710 for $3 \mathrm{CaO} \cdot \mathrm{Al}_{2} \mathrm{O}_{3}$ and a mean index of 1.715 for $3 \mathrm{CaO}^{-\mathrm{SiO}_{2}}$. Moreover, in iron-containing systems, the index of $3 \mathrm{CaO} \cdot \mathrm{Al}_{2} \mathrm{O}_{3}$ may be raised (2), so that its index may be the same or somewhat higher than that of $3 \mathrm{CaO} . \mathrm{SiO}_{2}$. And, although $3 \mathrm{CaO} . \mathrm{SiO}_{2}$ is birefracting, yet its birefraction is so low that in small grains it may not be evident. Because of these difficulties, microscopical examinations have only seldom detected $3 \mathrm{CaO} \cdot \mathrm{Al}_{2} \mathrm{O}_{3}$ in cements and theories, such as solid solution formation, have been advanced to explain this failure of positive identification.

Although optical similarities made the microscopical examination unsatisfactory as a means for the identification of $3 \mathrm{CaO} \cdot \mathrm{Al}_{2} \mathrm{O}_{3}$ in the presence of $3 \mathrm{CaO} . \mathrm{SiO}_{2}$, distinct differences in the X-ray diffraction patterns of those two compounds would appear to provide, in the X-ray method, a reliable means for such an identification. If the $3 \mathrm{CaO} \cdot \mathrm{Al}_{2} \mathrm{O}_{3}$ exists as such in a sintered mixture with $3 \mathrm{CaO} \cdot \mathrm{SiO}_{2}$ and $2 \mathrm{CaO} \cdot \mathrm{SiO}_{2}$, the X-ray diffraction patterns of the aluminate will be superimposed upon those of the other two compounds. But if the $3 \mathrm{CaO} \cdot \mathrm{Al}_{2} \mathrm{O}_{3}$ enters into a solid solution with either of the calcium silicates, the pattern will show the lines of that silicate in a uniformly shifted position with reference to the location they would occupy if the compound were in pure state. Likewise, if either silicate entered into solid solution with the aluminate, the pattern of the aluminate would occupy a shifted position.

To study this problem, a sample of $\mathrm{CaO}, \mathrm{Al}_{2} \mathrm{O}_{3}$, and $\mathrm{SiO}_{2}$ was mixed to form a composition represented by 47 per cent $3 \mathrm{CaO} \cdot \mathrm{SiO}_{2}$, 47 per cent $2 \mathrm{CaO} \cdot \mathrm{SiO}_{2}$, and 6 per cent $3 \mathrm{CaO} \cdot \mathrm{Al}_{2} \mathrm{O}_{3}$. This sample was burned at $1,500^{\circ} \mathrm{C}$., reground, and burned at $1,525^{\circ} \mathrm{C}$., following which treatment it showed no free lime by White's test. A mechanical mixture of the pure compounds in the proportion 47 per cent $3 \mathrm{CaO} . \mathrm{SiO}_{2}, 47$ per cent $\beta 2 \mathrm{CaO} . \mathrm{SiO}_{2}$, and 6 per cent $3 \mathrm{CaO} \cdot \mathrm{Al}_{2} \mathrm{O}_{3}$ was then made. These two samples were exposed to $\mathrm{X}$-radiation on the same film, hence, under exactly the same conditions.

The two patterns shown in Figure 2 appear to be identical in every respect, both in the position and in the intensity of the lines. Each of the compounds was definitely identified. Very careful measurement revealed only such slight differences as would obtain 
by repeated measurements on the same pattern. Several additional comparisons of the same character were made on compositions containing up to 15 per cent of $3 \mathrm{CaO} \cdot \mathrm{Al}_{2} \mathrm{O}_{3}$, but the results obtained were similar to those just described. This demonstrates that the pattern of none of those compounds is shifted when sintered preparations are obtained in the system $\mathrm{CaO}-\mathrm{Al}_{2} \mathrm{O}_{3}-\mathrm{SiO}_{2}$ in compositions similar to Portland cement clinker. The experiment confirms extensive tests that have been made in this laboratory on commercial and laboratory cements. In a great many of these, tricalcium aluminate has definitely been identified, but in none of them has there been observed any shift in the position of the patterns, either of the aluminate or the silicates. The data constitute convincing evidence that solid solutions are not formed between tricalcium aluminate and either tri-or di-calcium silicate in amounts sufficient to be detected by X-ray means.

\section{FREE LIME}

In a study reported from this laboratory (20), it was indicated that free $\mathrm{CaO}$ does not occur in Portland cements in amounts exceeding 3 per cent, and that probably the content is generally less than 2 per cent. The method used for determining the free $\mathrm{CaO}$ was the ammonium acetate method (21), the results of which were confirmed qualitatively by White's (22) test. Nacken (7), however, has reported that commercial cements may contain significant amounts of fine-grained $\mathrm{CaO}$ as determined by the $\mathrm{X}$-ray method.

Nacken obtained his evidence for the presence of free $\mathrm{CaO}$ in cements from pinhole diffraction patterns. These diagrams consist of a series of concentric circles; identification of a compound is effected by the measurement of the diameters and relative intensities of the lines of the circles.

As a matter of interest, pinhole photographs were made in this laboratory of a commercial clinker, $3 \mathrm{CaO} \cdot \mathrm{SiO}_{2}$ and $\mathrm{CaO}$.

The diameters of the circles and relative intensities are recorded in Table 5.

$\mathrm{T}_{\mathrm{ABLE}}$ 5.-Pinhole $\mathrm{X}$-ray data on a cement clinker, $3 \mathrm{CaO} . \mathrm{SiO}_{2}$ and $\mathrm{CaO}$

\begin{tabular}{|c|c|c|}
\hline Clinker & $3 \mathrm{CaO} \cdot \mathrm{SiO}_{2}$ & $\mathrm{CaO}$ \\
\hline $\begin{array}{l}3.73 \mathrm{~m} \\
4.08 \mathrm{ss} \ldots \\
4.35 \mathrm{ss} \ldots \\
4.95 \mathrm{ww} . \ldots . \\
5.25 \mathrm{~m} .\end{array}$ & $\begin{array}{l}3.70 \mathrm{~m} \\
4.07 \mathrm{ss} \\
4.35 \mathrm{~s}- \\
4.95 \mathrm{ww} \\
5.23 \mathrm{~m}\end{array}$ & $\begin{array}{l}\text { 4. } 05 \mathrm{~m} \text {. } \\
\text { 4. } 75 \mathrm{ss} \text {. }\end{array}$ \\
\hline $\begin{array}{l}6.03 \mathrm{ww} \\
6.67 \mathrm{sb} \ldots \\
7.35 \mathrm{~m} \\
7.75 \mathrm{w} \\
8.15 \mathrm{~m} . . . . . .\end{array}$ & $\begin{array}{l}6.00 \mathrm{ww} \\
6.65 \mathrm{~s}-\ldots \\
7.34 \mathrm{w} \\
7.78 \mathrm{w} \\
8.13 \mathrm{~m}\end{array}$ & $\begin{array}{l}6.95 \mathrm{~s} \text {. } \\
8.39 \mathrm{~m} \text {. } \\
8.90 \mathrm{~m} \text {. }\end{array}$ \\
\hline
\end{tabular}

An examination of these data show that there is no similarity between the patterns of $\mathrm{CaO}$ and cement clinker while the patterns of $3 \mathrm{CaO} . \mathrm{SiO}_{2}$ and this particular clinker correspond within the limit of accuracy by this method. No further studies were made with pinhole diagrams since the method described in this report is a development which gives far superior resolution of the lines from which measurements of greater accuracy may be obtained. 
A study was then made of the adaptability of the X-ray method for identifying $\mathrm{CaO}$ in cements. A commercial raw mixture was obtained and burned at different temperatures. One portion, burned at $1,435^{\circ} \mathrm{C}$. was found, by the ammonium acetate method, to contain 2.8 per cent of free $\mathrm{CaO}$. Another portion, burned at $1,500^{\circ} \mathrm{C}$. was found to contain 0.1 per cent of free $\mathrm{CaO}$. The chemical analysis of this clinker and the calculated composition (23) of the clinkers obtained at the two temperatures are given in Table 6.

TABLE 6.-Chemical analysis and calculated compound composition of a clinker burned at $1,435^{\circ}$ and $1,500^{\circ} \mathrm{C}$.

\begin{tabular}{|c|c|c|c|c|}
\hline \multicolumn{2}{|c|}{ Chemical analysis } & \multicolumn{2}{|c|}{ Calculated composition at $1,435^{\circ} \mathrm{C}$. } & \multirow{2}{*}{$\begin{array}{l}\text { Calculated } \\
\text { composi- } \\
\text { tion at } \\
1,500^{\circ} \mathrm{C} \text {. } \\
\text { (Per cent) }\end{array}$} \\
\hline Oxides & Per cent & Compounds & Per cent & \\
\hline $\begin{array}{l}\mathrm{CaO} \\
\mathrm{Al}_{2} \mathrm{O}_{3} \\
\mathrm{Fe}_{2} \mathrm{O}_{3} \\
\mathrm{SiO}_{2} \\
\mathrm{M} \mathrm{IgO}\end{array}$ & $\begin{array}{r}64.7 \\
5.8 \\
2.7 \\
24.1 \\
1.8\end{array}$ & $\begin{array}{l}3 \mathrm{CaO} \cdot \mathrm{SiO}_{2} \\
2 \mathrm{CaO} \cdot \mathrm{SiO}_{2} \\
3 \mathrm{CaO} \cdot \mathrm{Al}_{2} \mathrm{O}_{3} \\
4 \mathrm{CaO} \cdot \mathrm{Al}_{2} \mathrm{O}_{3} \cdot \mathrm{Fe}_{2} \mathrm{O}_{3} \\
\mathrm{MgO} \\
\mathrm{CaO}\end{array}$ & $\begin{array}{c}26 \\
50 \\
11 \\
8 \\
1.8 \\
2.8\end{array}$ & $\begin{array}{l}37 \\
41 \\
11 \\
8 \\
1.8 \\
.1\end{array}$ \\
\hline
\end{tabular}

Table 7 contains the X-ray diffraction data obtained on the two clinkers, together with the interplanar spacings and intensities of the lines for $\mathrm{CaO}, 3 \mathrm{CaO} \cdot \mathrm{SiO}_{2}, \beta 2 \mathrm{CaO} \cdot \mathrm{SiO}_{2}$ and $3 \mathrm{CaO} \cdot \mathrm{Al}_{2} \mathrm{O}_{3}$.

TABLE 7.-Interplanar spacings of diffraction patterns of a cement composition burned at two different temperatures, together with the interplanar spacings of the lines of $3 \mathrm{CaO} . \mathrm{SiO}_{2}, \beta 2 \mathrm{CaO} . \mathrm{SiO}_{2}, 3 \mathrm{CaO} . \mathrm{Al}_{2} \mathrm{O}_{3}$ and $\mathrm{CaO}$ which may be observed when those compounds are present in mixtures approximating the composition of Portland cement clinker

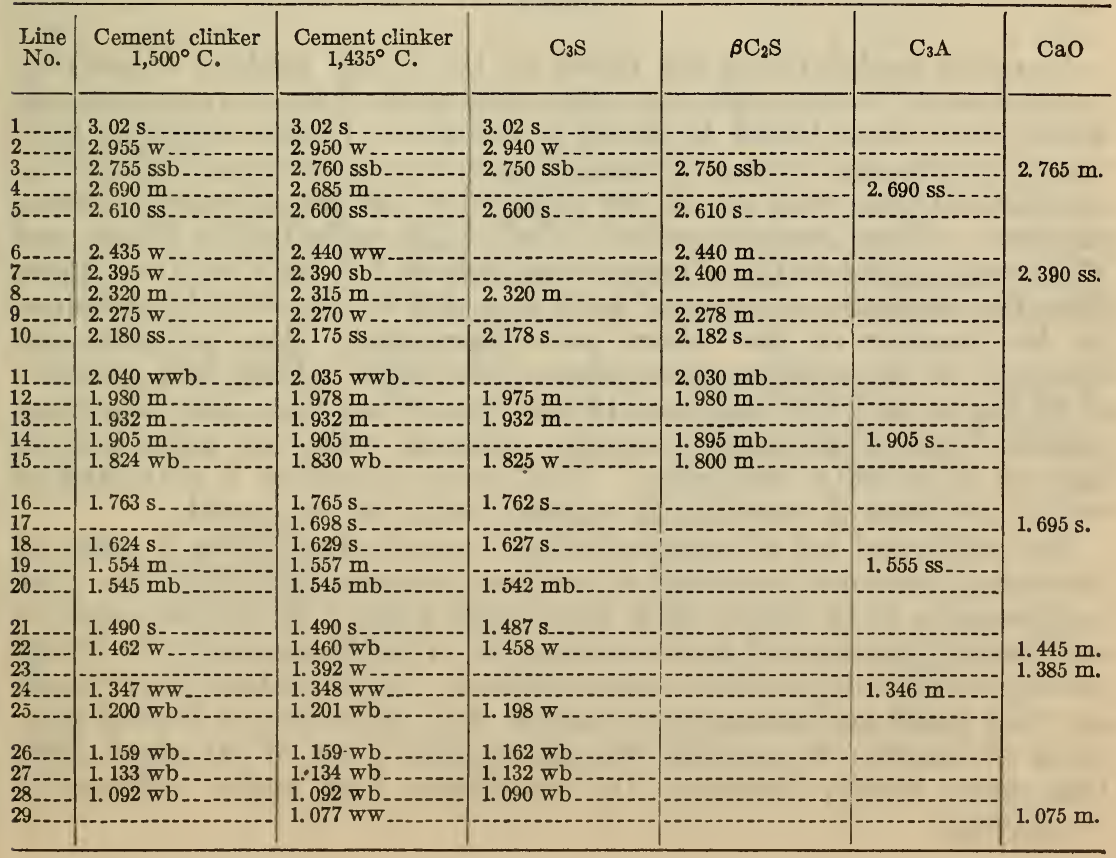


It will be observed that the patterns of the two differently burned samples are not identical. The points of difference lie in the lines which are characteristic of $\mathrm{CaO}$. Lines 17,23 , and 29 , which are found to be due to $\mathrm{CaO}$ and are not found in the pattern of any of the other compounds, are present in the X-ray pattern of the material burned at $1,435^{\circ}$ C., but are absent in the pattern of the sample burned at $1,500^{\circ} \mathrm{C}$. Furthermore, the strength and breadth of line No. 7 and the breadth of line No. 22 from the low-burned sample indicate that those lines are due to the strong corresponding lines of $\mathrm{CaO}$ rather than to the medium and weak corresponding lines of the $\beta 2 \mathrm{CaO} . \mathrm{SiO}_{2}$ and $3 \mathrm{CaO} . \mathrm{SiO}_{2}$, respectively. These data show that the free $\mathrm{CaO}$ of the low-burned sample can be positively identified by this means.

In Figure 3 the upper pattern is that of the clinker burned at $1,435^{\circ} \mathrm{C}$., which contains 2.8 per cent uncombined $\mathrm{CaO}$. The lower pattern is that of the sample burned nearly free of uncombined $\mathrm{CaO}$ at $1,500^{\circ} \mathrm{C}$. Two lines show up prominently in the upper pattern that are very weak and absent, respectively, in the lower pattern. These are the lines No. 7 and 17 of Table 7. The other differences, noted on the original film, are not observable on the print.

Many other examinations of a similar character indicate that the free $\mathrm{CaO}$ may be detected in cements when present to the extent of 2.5 per cent. Of 28 commercial cements examined, however, the lines of free $\mathrm{CaO}$ have not been observed in a single case. This is convincing evidence that free $\mathrm{CaO}$ does not occur generally in modern rotary kiln clinkers in amounts as high as 2.5 per cent, and confirms the evidence obtained by chemical and microscopical tests.

\section{VIT. LIMITING AMOUNTS REQUIRED FOR IDENTIFICA- TION}

In order to determine the effect on the X-ray pattern of varying proportions of compounds, mixtures were made of the pure compounds which have been found to occur in cement. Thus a series of mixtures was prepared which contained various proportions of $3 \mathrm{CaO} \cdot \mathrm{SiO}_{2}$ and $\beta 2 \mathrm{CaO} . \mathrm{SiO}_{2}$, and the X-ray diffraction pattern obtained of each mixture. Other series in which $3 \mathrm{CaO} \cdot \mathrm{Al}_{2} \mathrm{O}_{3}, 4 \mathrm{CaO} \cdot \mathrm{Al}_{2} \mathrm{O}_{3} \cdot \mathrm{Fe}_{2} \mathrm{O}_{3}$, and $\mathrm{MgO}$ were added to the silicates were included. By a study of these films the minimum amount of each material which could be detected in the presence of the others was determined. Also an idea was obtained of the relative intensities of the lines. Thus in a mixture of 85 per cent $3 \mathrm{CaO} . \mathrm{SiO}_{2}$ and 15 per cent $2 \mathrm{CaO} . \mathrm{SiO}_{2}$, only the most intense lines of $2 \mathrm{CaO} . \mathrm{SiO}_{2}$ appear, whereas only the least intense lines of $3 \mathrm{CaO} \cdot \mathrm{SiO}_{2}$ disappear. This series furnished a standard to which the films of commercial cements could be compared.

An additional set of standard films was obtained from a series of laboratory cements prepared of various compositions from the pure components: $\mathrm{CaO}, \mathrm{Al}_{2} \mathrm{O}_{3}, \mathrm{SiO}_{2}, \mathrm{Fe}_{2} \mathrm{O}_{3}$, and $\mathrm{MgO}$. It was felt that in mechanical mixtures of pure compounds, crystals are apt to be better developed than in sintered cement clinkers. In the latter, the crystals are very small and intimately mixed so that this series of burned mixtures of known composition should furnish a set of standard films that more closely resemble the conditions met under commercial conditions. 
From these studies there was determined under the conditions of test, the minimum amount of one compound which could be detected in the presence of the other compounds of the mixture. These results may be summarized as follows:

It was found by the X-ray method that in the laboratory burns, $\beta 2 \mathrm{CaO} . \mathrm{SiO}_{2}$ could be identified definitely in the presence of $3 \mathrm{CaO} \mathrm{SiO}_{2}$ only when the amount of $\beta 2 \mathrm{CaO} . \mathrm{SiO}_{2}$ reached 15 per cent. This is due to the circumstances that the more intense lines of $\beta 2 \mathrm{CaO} \cdot \mathrm{SiO}_{2}$, which are the ones to appear when small amounts of $\beta 2 \mathrm{CaO} \cdot \mathrm{SiO}_{2}$ are present, nearly or quite coincide with lines of $3 \mathrm{CaO} \cdot \mathrm{SiO}_{2}$. Only when this minimum amount of $\beta 2 \mathrm{CaO} \cdot \mathrm{SiO}_{2}$ is reached do the weaker lines of that compound appear whereby it may be identified and its presence confirmed. Under unfavorable conditions; for example, poor crystallization, it is probable that greater amounts may be necessary for identification.

The amount of $3 \mathrm{CaO} \cdot \mathrm{SiO}_{2}$ which can be identified in the presence of $\beta 2 \mathrm{CaO} . \mathrm{SiO}_{2}$, or in cement clinkers may be as low as 8 per cent.

Because of the high order of symmetry and relatively simple structure of the crystals of $\mathrm{CaO}, \mathrm{MgO}$, and $3 \mathrm{CaO} \cdot \mathrm{Al}_{2} \mathrm{O}_{3}$, most of the lines in the patterns of these compounds are intense and, therefore, appear when only small percentages of those compounds are present. In mixtures of compounds approaching Portland cement clinker in composition, the minimum amount of $\mathrm{MgO}$ which could be detected was about 2.5 per cent; $\mathrm{CaO}$ about 2.5 per cent, and $3 \mathrm{CaO} \cdot \mathrm{Al}_{2} \mathrm{O}_{3}$ about 6 per cent.

$4 \mathrm{CaO} \cdot \mathrm{Al}_{2} \mathrm{O}_{3} \cdot \mathrm{Fe}_{2} \mathrm{O}_{3}$, like $\beta 2 \mathrm{CaO} \cdot \mathrm{SiO}_{2}$, gives a diffraction pattern containing only a few intense lines. And in cement like compositions these lines nearly or quite coincide with lines of the other compounds. Therefore, to identify this comopund, especially in the presence of $3 \mathrm{CaO} \cdot \mathrm{Al}_{2} \mathrm{O}_{3}$ or $\beta 2 \mathrm{CaO} . \mathrm{SiO}_{2}$, the minimum amount required is about 10 per cent in mixtures of the pure compounds and about 15 per cent in cement clinker. The larger amount required in clinkers may be due to poorer crystal formation; the combination of some of the $\mathrm{Fe}_{2} \mathrm{O}_{3}$ or $\mathrm{Al}_{2} \mathrm{O}_{3}$ with alkalies or other minor constituents which can not yet be evaluated in the calculations; or to the failure of some of the $4 \mathrm{CaO} \cdot \mathrm{Al}_{2} \mathrm{O}_{3} \cdot \mathrm{Fe}_{2} \mathrm{O}_{3}$ to crystallize. Thus Hansen (24) has observed that the iron phase frequently remains as a glass in the presence of silicates. If $3 \mathrm{CaO} \cdot \mathrm{Al}_{2} \mathrm{O}_{3}$ is absent, or present only in small amounts, the quantity of $4 \mathrm{CaO} \cdot \mathrm{Al}_{2} \mathrm{O}_{3} \cdot \mathrm{Fe}_{2} \mathrm{O}_{3}$ necessary for identification in clinkers is less than 15 per cent.

To summarize, in laboratory clinkers, the following amounts of crystalline phase must ordinarily be present in order to be susceptible of recognition by the X-ray diffraction method as employed in this study.

Per cent

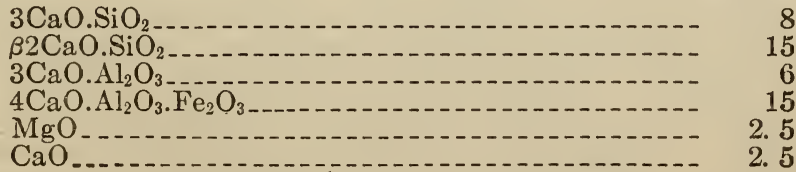




\section{EXAMINATION OF COMMERCIAL CEMENT CLINKERS}

Twenty-eight commercial clinkers were examined by the X-ray diffraction method in the attempt definitely to identify the compounds present in them and to correlate the results obtained by $\mathrm{X}$-ray examination with the composition as calculated from chemical analysis. These clinkers represent a variety of types of raw material and methods of manufacture, both domestic and foreign.

Table 8 gives the chemical analyses of three of these commercial clinkers, together with the compounds present as obtained by calculation (23). It should be pointed out that the status of equilibrium is taken into consideration in the calculations by means of the value obtained for the free $\mathrm{CaO}$ content.

TABLE 8.-Chemical analyses and calculated compound composition of three commercial cement clinkers

\begin{tabular}{|c|c|c|c|}
\hline Chemical analysis & $\begin{array}{l}\text { Clinker } \\
\text { No. } 1\end{array}$ & $\begin{array}{c}\text { Clinker } \\
\text { No. } 2\end{array}$ & $\begin{array}{l}\text { Clinker } \\
\text { No. } 3\end{array}$ \\
\hline $\begin{array}{l}\mathrm{CaO} \\
\mathrm{Al}_{2} \mathrm{O}_{3} \\
\mathrm{Fe}_{2} \mathrm{O}_{3} \\
\mathrm{MgO}\end{array}$ & $\begin{array}{r}63.4 \\
6.6 \\
2.6 \\
4.1 \\
.06\end{array}$ & $\begin{array}{l}64.5 \\
6.4 \\
2.4 \\
3.1 \\
.03\end{array}$ & $\begin{array}{r}66.0 \\
4.4 \\
5.1 \\
.6\end{array}$ \\
\hline $\begin{array}{l}\mathrm{SiO}_{2} \\
\mathrm{SO}_{3} \\
\mathrm{LosS} \\
\text { Free } \mathrm{CaO}-\end{array}$ & $\begin{array}{r}22.8 \\
.2 \\
.1 \\
.0\end{array}$ & $\begin{array}{r}22.8 \\
.2 \\
.5 \\
.4\end{array}$ & $\begin{array}{r}24.0 \\
.0 \\
-.0\end{array}$ \\
\hline Compound composition & \multirow[b]{2}{*}{$\begin{array}{c}37 \\
38 \\
13 \\
0 \\
8 \\
4.1 \\
.3\end{array}$} & \multirow[b]{2}{*}{$\begin{array}{l}41 \\
35 \\
13 \\
7^{\circ} \\
3.1 \\
.3\end{array}$} & \multirow[b]{2}{*}{$\begin{array}{r}50 \\
31 \\
3 \\
0 \\
15 \\
0 \\
0\end{array}$} \\
\hline $\begin{array}{l}3 \mathrm{CaO} . \mathrm{SiO}_{2} \\
2 \mathrm{CaO} \mathrm{SiO}_{2} \\
3 \mathrm{CaO} \mathrm{Al}_{2} \mathrm{O}_{3} \\
\mathrm{CaO}-\mathrm{AaO}_{2} \mathrm{Al}_{2} \mathrm{O}_{3} \cdot \mathrm{Fe}_{2} \mathrm{O}_{3} \\
\mathrm{MgO} \\
\mathrm{CaSO} \mathrm{S}_{4}\end{array}$ & & & \\
\hline
\end{tabular}

Table 9 gives the interplanar spacings and relative intensities of the lines of the X-ray diffraction patterns of these clinkers, together with corresponding data for the compounds to which the lines may be assigned. In the diffraction patterns of the pure compounds, the weakest lines are omitted, since such lines do not appear when the concentrations of the compounds are of the order found to obtain in cements. Complete diffracticn data on these compounds have been reported from this laboratory (11). 
TABLE 9.-Interplanar spacings of diffraction patterns of three commercial clinkers, together with the interplanar spacings of the lines of the cement compounds which may be observed when those compounds are present in amounts approximating the quantities predicted in Portland-cement clinker

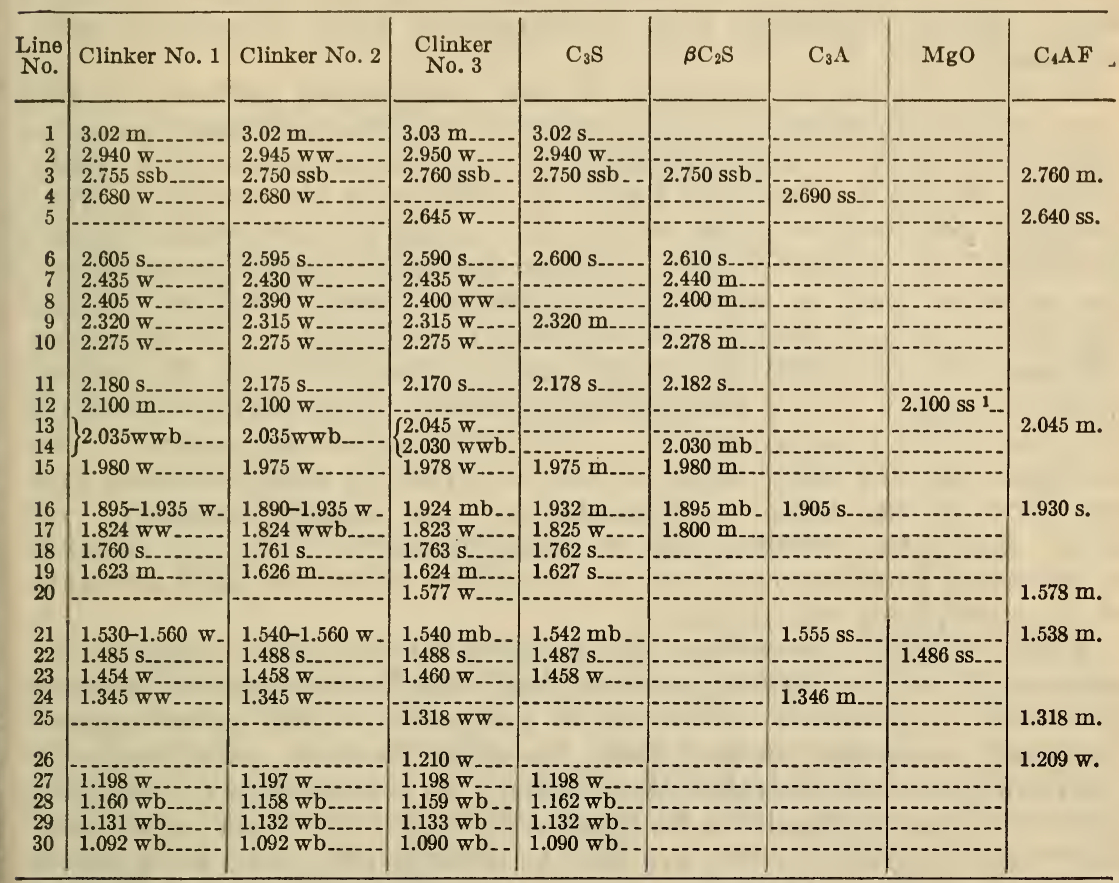

${ }^{1} \mathrm{~A}$ typographical error appeared in a previous publication $(A m . J$. Sci., 15, p. 225; 1928) in which the line 2.100 ss for MgO was incorrectly listed $2.01 \mathrm{~m}$.

An examination of the diffraction data shows that there can be identified in clinkers 1 and 2 the compounds $3 \mathrm{CaO} . \mathrm{SiO}_{2}, \beta 2 \mathrm{CaO} \cdot \mathrm{SiO}_{2}$, $3 \mathrm{CaO} \cdot \mathrm{Al}_{2} \mathrm{O}_{3}$ and $\mathrm{MgO}$. The compound $4 \mathrm{CaO} \cdot \mathrm{Al}_{2} \mathrm{O}_{3} \cdot \mathrm{Fe}_{2} \mathrm{O}_{3}$, present (by calculation) to the extent of 8 and 7 per cent, respectively, was not definitely identified in those two clinkers.

In clinker No. 3, which contained (by calculation) 3 per cent of $3 \mathrm{CaO} \cdot \mathrm{Al}_{2} \mathrm{O}_{3}, 15$ per cent of $4 \mathrm{CaO} \cdot \mathrm{Al}_{2} \mathrm{O}_{3} \cdot \mathrm{Fe}_{2} \mathrm{O}_{3}$, and 0.6 per cent of $\mathrm{MgO}$, only the lines of $4 \mathrm{CaO} \cdot \mathrm{Al}_{2} \mathrm{O}_{3} \cdot \mathrm{Fe}_{2} \mathrm{O}_{3}$ were identified in the pattern in addition to those of $3 \mathrm{CaO} . \mathrm{SiO}_{2}$ and $\beta 2 \mathrm{CaO} . \mathrm{SiO}_{2}$. The low concentration of the $3 \mathrm{CaO} \cdot \mathrm{Al}_{2} \mathrm{O}_{3}$ and $\mathrm{MgO}$ accounts for the absence of the lines of those compounds in the pattern.

These three clinkers were selected for detailed presentation because they are typical and represent rather widely varying compositions. Twenty-five other commercial-cement clinkers were examined by this method. In all of them, without exception, $3 \mathrm{CaO} . \mathrm{SiO}_{2}$ and $\beta 2 \mathrm{CaO}$.$\mathrm{SiO}_{2}$ were identified. Furthermore, the patterns of those two compounds were always the most prominent, indicating that they are the most abundant constituents of normal cement clinker. One or more of the compounds $3 \mathrm{CaO} \cdot \mathrm{Al}_{2} \mathrm{O}_{3}, 4 \mathrm{CaO} \cdot \mathrm{Al}_{2} \mathrm{O}_{3} \cdot \mathrm{Fe}_{2} \mathrm{O}_{3}$, or $\mathrm{MgO}$ were identified in most of the clinkers, but not all of these latter compounds were identified in all clinkers. As previously pointed out, the X-ray method fails to indicate the compounds when they are present in 
amounts less than a certain minimum value. In no case, however, has any inconsistency been observed between the computed constitution, due consideration always being given to the free $\mathrm{CaO}$, and the X-ray observations although, to bring out the desired relationships, special exposures and developments have sometimes been necessary.

No one method of approach to the complicated problem of the constitution of Portland cement may be regarded, of itself, as altogether conclusive. The separation of the compounds from a finely ground sample by methods based on differences in specific gravity probably can not be made complete because of the intimate intergrowth of the crystal phases. Microscopical examinations are satisfactory when made on especially prepared laboratory clinkers, but the fine structure and intergrowths of the constituents of commercial clinkers make for difficulties in the interpretation of optical data when applied directly to the commercial material. Calculations based on the phase-rule interpretations of chemical analyses are open to the criticism that the exact state of the equilibrium which obtains and the effect of the minor components are not known precisely. Of itself, the X-ray method also is inconclusive for it is not capable of detecting small amounts of a crystalline phase nor large amounts of an amorphous composition.

Taken together, however, the cogency of the data obtained by phase equilibria, chemical, microscopical, and X-ray methods becomes profoundly impressive. There is in no case a conflict in interpretation and, where one method fails, the other methods usually supply the information to complete the picture. It is especially noteworthy that the X-ray method can be applied directly to commercial clinker. The results obtained by it are not, to as large an extent as in phase equilibria studies, dependent upon a scientific deduction following established laws; but the confirmation of those deductions by the $\mathrm{X}$-ray method, as also by the microscopical method, leads to increased confidence in the findings.

The X-ray technique has not yet been developed to a degree where the method may be employed for the quantitative estimation of the compounds present. This is a problem to be studied in the near future.

\section{SUMMARY}

The X-ray method has been applied in recent research to a study of the compounds which may occur in Portland cement clinker. The present investigation is concerned with a number of subjects regarding the constitution of cement clinker and with the identification of the compounds that occur in the commercial material.

An examination of the composition $3 \mathrm{CaO}+\mathrm{SiO}_{2}$ has shown that $3 \mathrm{CaO} . \mathrm{SiO}_{2}$ exists and can be formed by the heating together, under the proper conditions, of a properly proportioned mixture of lime and silica. It is shown, furthermore, that $\mathrm{CaO}$ does not enter into solid solution with $2 \mathrm{CaO} . \mathrm{SiO}_{2}$ in appreciable amounts, but that compositions ranging between $2 \mathrm{CaO}+\mathrm{SiO}_{2}$ and $3 \mathrm{CaO}+\mathrm{SiO}_{2}$, properly heated, contain at equilibrium a mixture of $3 \mathrm{CaO} \cdot \mathrm{SiO}_{2}$ and either $\gamma$ or $\beta 2 \mathrm{CaO} . \mathrm{SiO}_{2}$.

$A$ study of the composition $8 \mathrm{CaO}+\mathrm{Al}_{2} \mathrm{O}_{3}+2 \mathrm{SiO}_{2}$ has shown that a compound of that composition does not exist in the system 
$\mathrm{CaO}-\mathrm{Al}_{2} \mathrm{O}_{3}-\mathrm{SiO}_{2}$ nor in Portland cement. On the contrary, such a mixture, properly heated gives $3 \mathrm{CaO} . \mathrm{SiO}_{2}, \beta 2 \mathrm{CaO} . \mathrm{SiO}_{2}$ and $3 \mathrm{CaO} \cdot \mathrm{Al}_{2} \mathrm{O}_{3}$ and, if equilibrium is not complete, a small amount of $\mathrm{CaO}$.

A special examination of the system $3 \mathrm{CaO} \cdot \mathrm{SiO}_{2}-2 \mathrm{CaO} \cdot \mathrm{SiO}_{2}-$ $3 \mathrm{CaO} . \mathrm{Al}_{2} \mathrm{O}_{3}$ has shown that solid solution does not occur between either of the above silicates and the aluminate in appreciable amounts. The mixtures at equilibrium contain only those three compounds..

Free $\mathrm{CaO}$ was not found in commercial cement clinkers by the X-ray method. A study of the identification of that compound indicates that a percentage of $\mathrm{CaO}$ of 2.5 could be recognized. Hence, it is demonstrated that free $\mathrm{CaO}$ is not commonly present in commercial clinkers in amounts as high as 2.5 per cent.

The minimum amounts of the cement compounds that could be detected in controlled laboratory burns by the X-ray method, as used in this study, were found to be as follows:

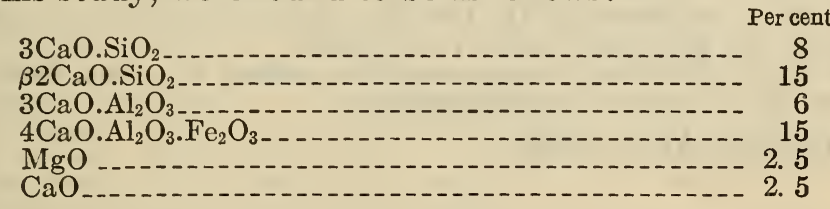

The X-ray diffraction patterns of 28 commercial Portland cement clinkers, representing many types of raw material and processes of manufacture, both domestic and foreign, were obtained. $3 \mathrm{CaO}^{\mathrm{S}} \mathrm{SiO}_{2}$ and $\beta 2 \mathrm{CaO} . \mathrm{SiO}_{2}$ were identified in each as unquestionably the most abundant constituents; $3 \mathrm{CaO} \cdot \mathrm{Al}_{2} \mathrm{O}_{3}, 4 \mathrm{CaO} \cdot \mathrm{Al}_{2} \mathrm{O}_{3} \cdot \mathrm{Fe}_{2} \mathrm{O}_{3}$, and $\mathrm{MgO}$ were identified, separately or together, in most of the clinkers but, in many of them, the patterns of one or two of these latter compounds were not observed.

The results obtained in this investigation by X-ray methods are in agreement with those obtained by phase equilibria, chemical and microscopical methods. Each supplements and confirms the other. Taken together, the cogency of their findings becomes convincing. These findings define the major constitution of Portland cement clinker. They indicate that the most abundant constituents are tricalcium silicate and beta dicalcium silicate; that there are normally present, in addition, tricalcium aluminate, tetracalcium alumino ferrite and magnesia; and that free $\mathrm{CaO}$ is not normally present in amounts as great as 2.5 per cent.

\section{BIBLIOGRAPHY}

1. Rankin, G. A., and Wright, F. E., Am. J. Sci., 39, p. 1; 1915.

2. Rankin, G. A., and Merwin, H. E., The System CaO- $\mathrm{Al}_{2} \mathrm{O}_{3}-\mathrm{MgO}$, J. Am. Chem. Soc., 38, p. 568; 1916; The System $\mathrm{MgO}-\mathrm{Al}_{2} \mathrm{O}_{3}-\mathrm{SiO}_{2}$, Am. J. Sci., 45, p. 301; 1916; Ferguson, J. B., and Merwin, H. E., The System CaO$\mathrm{MgO}-\mathrm{SiO}_{2}$, 48, p. 81; 1919; Hansen, W. C., and Bogue, R. H., The System $\mathrm{CaO}-\mathrm{Fe}_{2} \mathrm{O}_{3}-\mathrm{SiO}_{2}$, J. Am. Chem. Soc., 48, p. 1261; 1926; Hansen, W. C., Brownmiller, L. T., and Bogue, R. H., The System $\mathrm{CaO}-\mathrm{Al}_{2} \mathrm{O}_{3}-\mathrm{Fe}_{2} \mathrm{O}_{3}$, 50, p. 396; 1928; Hansen, W. C., The System $2 \mathrm{CaO} . \mathrm{SiO}_{2}-\mathrm{MgO}-5 \mathrm{CaO}$. $3 \mathrm{Al}_{2} \mathrm{O}_{3}, 50$, p. $3081 ; 1928$.

3. Hansen, W. C., and Bogue, R. H., Ind. Eng. Chem., 19, p. 1260; 1927; Hansen, W. C., B. S. Jour. Research, 4, (RP132); January, 1930.

4. Dyckerhoff, W., Dissertation, 1924; Zement, 16, p. 731; 1927.

5. Jänecke, E., Z. anorg. Chem., 76, p. 1357; 1912.

6. Kühl, H., Zement, 13, p. 512; 1924. 
7. Nacken, R., Zement, 16, p. 1017; 1927.

8. Debye, P., and Scherrer, P., Phys. Z., 17, p. 277; 1916; Hull, A. W., Phys. Rev., 10, p. 66; 1917; Davey, W. P., Gen. Elec. Rev., 25, p. 565; 1922.

9. Bragg, W. H., and W. L., X Rays and Crystal Structure, G. Ball \& Sons (London); Wyckoff, R. W. G., The Structure of Crystals, Chemical Catalogue Co., New York, N. Y., Clark, G. L., Applied X Rays, McGraw-Hill Book Co., New York, N. Y.

10. Hansen, W. C., J. Am. Ceram. Soc., 11, p. 68; 1928.

11. Harrington, E. A., Am. J. Sci., 13, p. 467; 1927; Hansen, W. C., and Brownmiller, L. T., 15, p. 225; 1928 . See also reference No. 10.

12. Harrington, E. A., J. Opt. Soc. Am., 16, p. 211; 1928.

13. Analysis by H. C. Stecker.

14. Jänecke, E., Zement, 18, p. 1345; 1929.

15. Rankin, G. A., and Wright, F. E., Z. anorg. Chem., 75, p. 63; 1912.

16. Hansen, W. C., Dyckerhoff, W., Ashton, F. W., and Bogue, R. H., J. Phys. Chem., 31, p. 607; 1927; Zement, 16, p. 51, 1927.

17. Goebel, H., Zement, 14, p. $548 ; 1925$.

18. Jänecke, E., Concrete, 35, p. 105; 1929.

19. Jänecke, E., Zement, 18, p. 756; 1929.

20. Lerch, Wm., Concrete, C. M. S., 35, pp. 109, 115; 1929.

21. Lerch, Wm., and Bogue, R. H., Ind. Eng. Chem., Anal. Ed., 2, p. 296; 1930.

22. White, A. H., Ind. Eng. Chem., 1, p. 5; 1909.

23. Bogue, R. H., Ind. Eng. Chem., analytical edition, 1, p. 192; 1929.

24. Hansen, W. C., personal communication.

Washingtoin, April, 1930. 